\title{
Production of Recombinant PRMT Proteins using the Baculovirus Expression Vector System
}

\author{
Ashley Hutchinson ${ }^{1}$, Almagul Seitova ${ }^{1}$ \\ ${ }^{1}$ Structural Genomics Consortium, University of Toronto
}

\section{Corresponding Author}

Almagul Seitova

alma.seitova@utoronto.ca

\section{Citation}

Hutchinson, A., Seitova, A. Production of Recombinant PRMT Proteins using the Baculovirus Expression Vector System. J. Vis. Exp. (173), e62510, doi:10.3791/62510 (2021).

\section{Date Published}

July 17,2021

DOI

$10.3791 / 62510$

URL

jove.com/video/62510

\section{Abstract}

Protein arginine methyltransferases (PRMTs) methylate arginine residues on a wide variety of proteins that play roles in numerous cellular processes. PRMTs can either mono- or dimethylate arginine guanidino groups symmetrically or asymmetrically. The enzymology of these proteins is a complex and intensely investigated area that requires milligram quantities of high-quality recombinant protein. The baculovirus expression vector system (BEVS) employing Autographa californica multiple nucleopolyhedrovirus (AcMNPV) and Spodoptera frugiperda 9 (Sf9) insect cells has been used for expression screening and production of many PRMTs, including PRMT 1, 2, and 4 through 9. To simultaneously screen for the expression of multiple constructs of these proteins, including domains and truncated fragments as well as the full-length proteins, we have applied scalable methods utilizing adjustable and programmable multichannel pipettes, combined with 24- and 96-well plates and blocks. Overall, these method adjustments enabled a large-scale generation of bacmid DNA, recombinant viruses, and protein expression screening. Using culture vessels with a high-fill volume of Sf9 cell suspension helped to overcome space limitations in the production pipeline for single batch large-scale protein production. Here, we describe detailed protocols for the efficient and cost-effective expression of functional PRMTs for biochemical, biophysical, and structural studies.

\section{Introduction}

Protein arginine methyltransferases (PRMTs) methylate arginine residues in a monomethyl or symmetric/asymmetric dimethyl fashion. The repetitive RG/RGG/GRG sequences are highly preferred by most PRMTs and are found in a wide variety of proteins ${ }^{1,2}$. Arginine methylated proteins such as histones or transcription factors and splicing factors regulate transcription, splicing, and chromatin structure ${ }^{3,4}$. Increasing knowledge of diverse regulation of substrate and cofactor utilization, turnover, and kinetics of PRMTs, as well as generation of selective inhibitors, have shed mechanistic light on these enzymes and their complexes ${ }^{5,6}$. However, not all PRMT family members are studied to the same extent; 
for example, PRMT9 was only recently discovered to be a member of the PRMT family ${ }^{1}$. Structure and enzyme function studies for these proteins require sufficient, often milligram, quantities of recombinant protein to be available.

The Escherichia coli (E. coli) prokaryotic expression system is usually the first choice for expression screening utilizing multiple constructs for a given protein $7,8,9$. However, $E$. coli-based expression does not always result in sufficient quantities of PRMT proteins in their active forms, as we have noted in particular for PRMT5 and PRMT7 (see below). Thus, PRMTs that failed to express in E. coli or needed to be produced by the eukaryotic expression machinery were subcloned into vectors appropriate for the expression screening in the alternative baculovirus expression vector system (BEVS). While E. coli expressed samples of PRMT1, PRMT3 and PRMT8 have been utilized extensively for in vitro assays and crystallography, other PRMTs such as PRMT5, which requires MEP50 binding partner of its dual methyltransferase domain, and PRMTs such as PRMT7 and 9, necessitate insect cell expression to obtain sufficient quantities of active protein. Overall, the standardized medium-throughput methyltransferase assays for PRMT4, 5, 6, 7, and 9 have utilized the BEVS in insect cells $^{6}$. The baculovirus expression vector system (BEVS) is a versatile platform to produce recombinant proteins requiring the eukaryotic expression machinery that enables post-translational modifications essential for biochemical, biophysical, and structural studies ${ }^{10,11,12}$. Several BEVSs have become commercially available since the first reported use of baculoviruses in 1983 for protein expression ${ }^{13}$. Most of these protocols employ different strategies for the transfer of the expression plasmid into insect cells. These include Bac-to-Bac, flashBAC, BaculoGOLD Bright, BacVector-3000, BacMagic, BacPAK, etc. Our protocol is based on the most commonly used system in BEVS, the Bac-to-Bac system ${ }^{14}$, which is designed to transfer the gene/cDNA encoding the protein of interest (POI, here the PRMTs) into the baculovirus genome maintained in a specialized strain of $E$. coli via sitespecific transposition $^{15}$.

Briefly, the plasmid transfer vector containing the gene of interest was transformed into $\mathrm{DH} 10 \mathrm{Bac} E$. coli competent cells to generate recombinant viral bacmid DNA. Adherent Sf9 cells were then transfected with bacmid DNA. Four to five days after transfection, initial recombinant baculoviruses secreted into the cell culture medium were recovered and labeled as the $\mathrm{P} 1$ virus. The $\mathrm{P} 1$ baculovirus stocks were then used for virus amplification (i.e., generation of P2 baculovirus stocks) and protein expression screening. Based on the expression screening results, $\mathrm{P} 2$ viruses for the best expression construct of the protein were identified and used to generate suspension cultures of baculovirus-infected insect cells (SCBIIS) for the large-scale protein production. Here, we describe our detailed protocols and describe the rationale behind our reagent and culture vessel choices to support our strategy of developing a more time-efficient, cost-efficient, and scalable methodology to obtain sufficient quantities of desired recombinant proteins.

\section{Protocol}

NOTE: The overview of the BEVS protocol steps is outlined in Figure 1.

\section{Generation of a recombinant bacmid DNA}

1. Preparation of LB agar selective plates for $\mathrm{DH} 10 \mathrm{Bac}$ transformation

1. Prepare LB agar plates containing: $50 \mu \mathrm{gg} /$ $\mathrm{mL}$ kanamycin, $7 \mu \mathrm{g} / \mathrm{mL}$ gentamicin, $10 \mu \mathrm{g} / \mathrm{mL}$ 
tetracycline, $200 \mu \mathrm{g} / \mathrm{mL}$ Bluo-gal, and $40 \mu \mathrm{g} / \mathrm{mL}$ IPTG to select for DH10Bac transformants.

2. Weigh $25 \mathrm{~g}$ of premixed LB broth and $13 \mathrm{~g}$ of Bacto Agar and put into $2 \mathrm{~L}$ flask. Bring the volume to 1 $\mathrm{L}$ with distilled water and autoclave for $15-30 \mathrm{~min}$ at $121^{\circ} \mathrm{C}$.

3. Set a water bath at $50{ }^{\circ} \mathrm{C}$ and cool the autoclaved agar solution in the water bath for $40-60$ min until it is cooled down to $50-55^{\circ} \mathrm{C}$.

4. To the cooled solution, add gentamicin to a final concentration of $7 \mu \mathrm{g} / \mathrm{mL}$, kanamycin to a final concentration of $50 \mu \mathrm{g} / \mathrm{mL}$, tetracycline to a final concentration of $10 \mu \mathrm{g} / \mathrm{mL}$, Bluo-gal to a final concentration of $200 \mu \mathrm{g} / \mathrm{mL}$, and IPTG to a final concentration of $40 \mu \mathrm{g} / \mathrm{mL}$.

5. Mix the agar solution and aliquot $7-10 \mathrm{~mL}$ of the medium to each $60 \mathrm{~mm}$ plate using a $50 \mathrm{~mL}$ pipette. Let the plates sit at room temperature $(2 \mathrm{~h})$ to harden. Invert, wrap and store at $4{ }^{\circ} \mathrm{C}$. Plates containing antibiotics are stable for up to 4 weeks.

2. Transformation of the plasmid into DH10Bac E. coli competent cells

1. Calculate the required volume of competent cells.

2. Thaw competent cells on ice, gently spin down and resuspend back by gentle tapping.

3. Use a 12-channel pipette to dispense $4 \mu \mathrm{L}$ of the cells into each well of the 96-well PCR plate.

4. Add $\sim 0.3-0.5 \mu \mathrm{g}$ of recombinant plasmid DNA to the competent cells and mix gently by tapping. Incubate the mixture on ice for 10-15 $\mathrm{min}$.

5. Heat-shock the mixture in a PCR machine at $42{ }^{\circ} \mathrm{C}$ for $45 \mathrm{~s}$. Chill on ice for $2 \mathrm{~min}$.
6. Dispense $0.5 \mathrm{~mL}$ of $\mathrm{SOC}$ medium to each well of the 96-well blocks (96-deep well $2.4 \mathrm{~mL}$ ).

7. Use a 12-channel pipette to transfer the transformed bacterial suspension into the corresponding well of the block and cover it with an airpore sheet.

8. Place the block in a shaking incubator at $37^{\circ} \mathrm{C}$ with medium agitation (205 rpm) for 4-5 h.

9. Evenly spread $30-50 \mu \mathrm{L}$ of the culture over the surface of the LB agar plate using sterile glass beads. Store the rest of the culture at $4{ }^{\circ} \mathrm{C}$.

10. Incubate the plates at $37^{\circ} \mathrm{C}$ until the color of the blue/white colonies is discernible (40-48 h). Discard the culture when enough white, large colonies are obtained on the plate.

11. To ensure that white colonies contain only recombinant bacmid DNA, re-streak one isolated white colony onto fresh LB agar plates containing antibiotics, bluo-gal, and IPTG to verify the phenotype.

12. Incubate for $48 \mathrm{~h}$ at $37^{\circ} \mathrm{C}$.

13. Pick one verified white colony from a re-streaked plate for the extraction of recombinant bacmid DNA.

3. Isolating recombinant bacmid DNA

1. Inoculate a single, isolated white colony into 3 $\mathrm{mL}$ of LB medium supplemented with $50 \mu \mathrm{g} / \mathrm{mL}$ kanamycin, $7 \mu \mathrm{g} / \mathrm{mL}$ gentamicin, and $10 \mu \mathrm{g} / \mathrm{mL}$ tetracycline in 24-well blocks (24-well blocks round bottom) and cover with an airpore sheet.

2. Grow at $37^{\circ} \mathrm{C}$ overnight with shaking at $250 \mathrm{rpm}$.

3. Centrifuge the 24 -well blocks at $2,100 \times g$ for $10 \mathrm{~min}$. Decant the supernatant, invert the block, and tap 
gently on an absorbent tissue paper. Add $250 \mu \mathrm{L}$ of solution 1 (cell resuspension solution) to each well.

4. Seal the blocks with tape pads or any other sealing films and place them onto a shaking platform at 75 rpm for 5-10 min. Check each well to ensure proper cell lysis, and resuspend if necessary, using a $1 \mathrm{~mL}$ tip.

5. Add $250 \mu \mathrm{L}$ of solution 2 (cell lysis solution) to each well, seal the blocks, and place onto a shaking platform at $75 \mathrm{rpm}$ for $30 \mathrm{~s}$ (to avoid crosscontamination of the samples, do not invert 24-well blocks) incubating at room temperature for $4 \mathrm{~min}$.

6. Add $250 \mu \mathrm{L}$ of solution 3 (neutralization solution), seal the blocks, and place onto the shaking platform at $75 \mathrm{rpm}$ for $30 \mathrm{~s}$. A thick white precipitate of protein and E. coli genomic DNA will form. Place the sample on ice for 10-15 min.

7. Centrifuge for $60 \mathrm{~min}$ at $2,100 \times \mathrm{g}$ at $4{ }^{\circ} \mathrm{C}$ to tightly pellet the white precipitate material. During centrifugation, label a new microcentrifuge tube and add $0.8 \mathrm{~mL}$ of absolute isopropanol.

8. Gently transfer the supernatant to the tube containing isopropanol, avoiding any white precipitate material. Mix by gently inverting the tube a few times and then place on ice for 5 to $10 \mathrm{~min}$. At this stage, the sample can be stored at $-20{ }^{\circ} \mathrm{C}$ overnight.

9. Centrifuge the sample for $15 \mathrm{~min}$ at $14,000 \times \mathrm{g}$ at 4 ${ }^{\circ} \mathrm{C}$. Remove the supernatant and add $0.5 \mathrm{~mL}$ of $70 \%$ ethanol to each tube. Invert the tube several times to wash the pellet. Centrifuge for $5 \mathrm{~min}$ at $14,000 \mathrm{x}$ $g$ at room temperature. (Optional: repeat wash)
10. Bring samples inside the laminar flow hood to ensure the plasmid preparation's sterility and remove as much of the supernatant as possible.

NOTE: The pellet may become dislodged from the bottom of the tube, so carefully watch the pellet when discarding the supernatant.

11. Air-dry the pellet inside the laminar flow hood for 15 - 20 min and dissolve the DNA in $50 \mu \mathrm{L}$ of filtered elution buffer, $10 \mathrm{mM}$ Tris- $\mathrm{Cl}$, pH 8.5 (make sure that pellets are not over-dried).

12. Since recombinant bacmid DNA is greater than 135 $\mathrm{kb}$ in size, to avoid shearing of DNA, dissolve the pellet by gentle tapping.

13. To verify the presence of the gene of interest in bacmid DNA, set up the PCR reaction mix in a 96well PCR plate.

14. Prepare the PCR mix as follows: $1 \mu \mathrm{L}$ of buffer, $0.2 \mu \mathrm{L}(10 \mathrm{mM}$ each $)$ of dNTPs, $0.1 \mu \mathrm{L}$ of Taq DNA polymerase, $0.1 \mu \mathrm{L}$ $(25 \mu \mathrm{M})$ of forward and reverse primers (BACV2FWD: tattccggattattcataccg; BACV2REV: ctctacaaatgtggtatggc), $1 \mu \mathrm{L}$ of bacmid DNA and $8 \mu \mathrm{L}$ of water.

15. Perform amplification of the target genes with initial denaturation for 2 min at $95^{\circ} \mathrm{C}$, followed by 25 cycles of $94{ }^{\circ} \mathrm{C}$ for $30 \mathrm{~s}, 55{ }^{\circ} \mathrm{C}$ for $30 \mathrm{~s}$, and $72{ }^{\circ} \mathrm{C}$ for 1 $\min / k b$.

16. Terminate the reaction after a final extension for 7 $\min$ at $72{ }^{\circ} \mathrm{C}$.

17. Analyze $10 \mu \mathrm{L}$ of the amplification product on $1 \%$ $(w / v)$ agarose gel containing nucleic acid staining solution by electrophoresis. 
18. Store the verified bacmid DNAs at $4{ }^{\circ} \mathrm{C}$.

\section{Generation of recombinant baculovirus stocks}

NOTE: Use exponentially growing Sf9 cells with a viability of $95 \%$ or greater for any step of the baculovirus expression protocol, including cell transfection for baculovirus generation, baculovirus volume amplification, protein expression screening, and protein production.

1. Transfection of Sf9 cells with Bacmid DNA and transfection reagents (T.R.) such as JetPrime or XtremeGENE 9.

NOTE: Trypan Blue staining and a hemocytometer can be used to determine viable cell counts and \% cell viability. Non-viable cells take up the stain and appear blue under the microscope while viable cells remain unstained. To calculate $\%$ cell viability, a total cell count is obtained (unstained and stained) and the viable cell count is divided by the total cell count and multiplied by 100.

1. Dilute the exponentially growing Sf9 cells to a final cell density of $4 \times 10^{5}$ cells $/ \mathrm{mL}$ in serum free insect media and pour into the sterile reagent reservoir.

2. Use a programmable multichannel pipette to seed $0.5 \mathrm{~mL}$ of the diluted Sf9 cells into each well of a 24well plate.

3. Label one well of the plate as a control (untransfected) and use it as a control to compare the transfected and non-transfected cells to assess for potential signs of infections.

4. After seeding the cells into the plates, gently rock the plates back and forth several times to ensure an even monolayer of cells. Do not swirl the plates because the cells will cluster into the center of the well.

5. Incubate the plates at $27^{\circ} \mathrm{C}$ for at least $1 \mathrm{~h}$ to allow for cell attachment to the culture plates.

6. Mix well the transfection reagent vial. For each transfection, add $2 \mu \mathrm{L}$ of the transfection reagent to $100 \mu \mathrm{L}$ of the transfection buffer. Any other unsupplemented insect medium can also be used. Deposit the diluted transfection reagent in a sterile reagent reservoir and gently mix for $10 \mathrm{~s}$.

7. Using a 12-channel pipette, transfer $102 \mu \mathrm{L}$ of the diluted transfection reagent into a sterile 96microwell plate.

8. Transfer $10 \mu \mathrm{L}$ of a $0.2 \mu \mathrm{g} / \mu \mathrm{L}$ solution of recombinant bacmid DNA into the corresponding well of a 96-well microwell plate and mix by gently shaking (tapping) the plate from the sides.

9. Incubate the transfection mixture for $15-20 \mathrm{~min}$ to enable complex formation.

10. Using an adjustable 6-channel pipette designed for transfer between 96- and 24-well plates, add the transfection mix onto the cells dropwise into corresponding wells of transfection plates and incubate for $4-5 \mathrm{~h}$ at $27^{\circ} \mathrm{C}$.

11. Gently rock the plates back and forth several times during the incubation time to ensure the even distribution of the transfection mixture over the cell monolayer.

12. $4-5 \mathrm{~h}$ after transfection, add $1.5 \mathrm{~mL}$ of insect serumfree medium supplemented with $10 \%(\mathrm{v} / \mathrm{v})$ final of heat inactivated fetal bovine serum and antibioticantimycotic to $1 \%(\mathrm{v} / \mathrm{v})$ final volume $(100 \mathrm{units} / \mathrm{mL}$ of 
penicillin, $100 \mu \mathrm{g} / \mathrm{mL}$ of streptomycin, and $0.25 \mu \mathrm{g} /$ $\mathrm{mL}$ of amphotericin B).

13. Incubate the cells in a $27^{\circ} \mathrm{C}$ incubator for $72-96 \mathrm{~h}$. Gently rock the transfection plates once a day when possible.

14. Look for signs of infection (SOI), evident in transfected cells at $72-96 \mathrm{~h}$ post-transfection (Figure 2). Keep in mind that the transfected cells will start producing the virus and further infect the culture; thus, look for the signs of infection.

NOTE: Signs of infection are structural changes in the insect cells, such as a $25-50 \%$ increase in the cell diameter, enlarged cell nuclei, uniformly rounded shape, loss of proliferation and adherence to the culture dish surface, as well as a decrease in cell viability (Figure 2. Baculovirus Infected and uninfected Sf9 cells).

\section{Small - scale protein expression screening and virus amplification}

1. Infection of Sf9 cells with P1 baculovirus stocks.

NOTE: 4-5 days after transfection, signs of infection should be evident in the transfected cells when compared to the control (untransfected) cells under an inverted microscope. The initial recombinant baculoviruses secreted into the cell culture medium should be ready to collect.

1. Seed $2 \times 10^{5}$ exponentially growing Sf9 cells in serum-free insect media into each well of the 24-well plates in a total volume of $2 \mathrm{~mL}$ for infection with $\mathrm{P} 1$ viruses to amplify virus volume (resulting in the generation of the $\mathrm{P} 2$ viruses).
2. After pipetting the cells into the plates, gently rock the plates, using back and forth motion to ensure an even monolayer. Do not swirl the plates because the cells will cluster into the center of the well.

3. Incubate the plates at $27^{\circ} \mathrm{C}$ for at least $1 \mathrm{~h}$ to allow for cellular adherence to the plate.

4. Dispense $4 \mathrm{~mL}$ of $\mathrm{Sf9}$ cells at a density of $3.5-4 \mathrm{x}$ $10^{6}$ in insect serum-free medium into each well of 24-well blocks to infect with P1 viruses for the protein expression screening.

NOTE: Label one well of the 24-well plates and 24well blocks as control and use as an uninfected control for comparison of infected and non-infected cells when looking for SOI.

5. Use a programmable electronic multichannel to allow the simultaneous collection of P1 viruses (step 2.1.13), infection of freshly seeded Sf9 cells (step 3.1.1) and infection of the suspension cells in the 24well blocks (step 3.1.4) with $150 \mu \mathrm{L}$ of $\mathrm{P} 1$ viruses.

6. Spin down the rest of the collected P1 viral stocks for $15 \mathrm{~min}$ at $17,970 \times \mathrm{g}$, transfer them into microcentrifuge tubes and store in the dark at $4{ }^{\circ} \mathrm{C}$.

7. Gently rock the 24-well plates (step 3.1.1) on a reciprocating shaker to ensure an even distribution of the added P1 viruses over the cell monolayer; repeat this a few times during the incubation time.

8. Cover the 24-well blocks with the suspension culture of infected Sf9 cells (step 3.1.4) with an airpore sheet.

9. Incubate the 24 -well blocks at $27^{\circ} \mathrm{C}$, shaking at 245 rpm for 72-96 h. 
10. Look for SOI within $72-96 \mathrm{~h}$ after infection time in the 24-well plates with P2 viruses (step 3.1.1) and in the 24-well blocks (step 3.1.4) with infected cells for the expression screening.

NOTE: 4-5 days after infection of Sf9 cells with P1 viruses, SOI should be evident in the infected cells when compared to the non-infected control cells under an inverted microscope.

11. Collect P2 viruses from 24-well plates, centrifuge for $15 \mathrm{~min}$ at $17,970 \times \mathrm{g}$, transfer them into microcentrifuge tubes and store in the dark at $4{ }^{\circ} \mathrm{C}$.

12. At $72-96 \mathrm{~h}$ post-infection, spray over the 24 -well blocks with $70 \%$ ethanol, bring into the laminar flow hood, and check the cell density and viability in a few wells by Trypan Blue staining.

13. Proceed to protein purification if cells have signs of infection and viability is close to $70-75 \%$ as assessed by Trypan Blue staining.

14. Pellet the cells by centrifuging the 24 -well blocks at $525 \times g$ at $4{ }^{\circ} \mathrm{C}$ for $15 \mathrm{~min}$. Discard the supernatant and thoroughly re-suspend the pellets in $1 \mathrm{~mL}$ of lysis buffer comprising 25 mM Tris pH 8.0, 300 mM $\mathrm{NaCl}, 0.6 \% \mathrm{NP}-40,2 \mathrm{mM}$ imidazole, $5 \%$ glycerol (v/ v) and $1 \mathrm{x}$ protease inhibitor cocktail (100x protease inhibitor cocktail comprises aprotinin $0.25 \mathrm{mg} / \mathrm{mL}$, leupeptin $0.25 \mathrm{mg} / \mathrm{mL}$, pepstatin A $0.25 \mathrm{mg} / \mathrm{mL}$; E-64 $0.25 \mathrm{mg} / \mathrm{mL})$.

15. Store the cell suspension at $-80{ }^{\circ} \mathrm{C}$ for the subsequent test purification (see 3.2.2).

2. Protein purification from frozen cell suspension in 24-well test-expression blocks.

1. Assembly of the binding block (Figure 3).
1. Place 3 overlapping layers of parafilm on the top of the 96-deep well block (96-deep well $2.4 \mathrm{~mL}$ ).

2. Place a 96-well filter plate (filter microplate, 96-well, polypropylene with $25 \mu \mathrm{m}$ ultra high molecular weight polyethylene membrane) on the top of the 96-deep well block.

3. Push down the filter plate to secure the tips into the parafilm to seal off the filter plate from the 96-well deep block.

4. Transfer $50 \mu \mathrm{L}$ of pre-equilibrated $50 \%$ Ni-NTA resin slurry into each well of the filter plate.

2. Test expression procedure

1. Place the frozen cell suspension (step 3.1.15) present in 24-well blocks in a water bath at RT for 5-10 $\mathrm{min}$, then shake at $450 \mathrm{rpm}$ for $20 \mathrm{~min}$.

2. Centrifuge the 24 -well blocks at $3,275 \times g$ for 15 $\min$.

3. Using a multichannel pipette, transfer the cleared lysates into a filter plate containing 50 $\mu \mathrm{L}$ of pre-equilibrated $50 \%$ Ni-NTA resin slurry (step 3.2.1.4) and seal the filter plate with a 96-well cap mat (96-well cap mat, for use with square well, $2 \mathrm{~mL}$ ).

NOTE: Use a few rubber bands to keep the binding block together during incubation and centrifugation steps.

4. Place the secured binding block for $45-60 \mathrm{~min}$ into a rotator in a cold room to incubate cleared lysates with Ni-NTA resin.

5. After incubation, carefully lift the filter plate and remove the parafilm layer from the surface of the 96-deep well block (step 3.2.1.1). 
6. Place back the filter plate on top of the 96-deep well block and spin down the secured binding block for 2 min at $235 \times \mathrm{g}$.

7. Wash bond Ni-NTA resin $2 x$ with $2 \mathrm{~mL}$ of washing buffer comprising $25 \mathrm{mM}$ Tris $\mathrm{pH}$ $8.0,300 \mathrm{mM} \mathrm{NaCl}, 5 \%$ glycerol, and $15 \mathrm{mM}$ imidazole.

8. Spin down the block with washing buffer each time for $5 \mathrm{~min}$ at $235 \times \mathrm{g}$ to ensure complete removal of residual liquid.

9. Transfer the filter plate on the top of the 96-well PCR plate containing $10 \mu \mathrm{L}$ of $4 x$ loading dye.

10. Add $40 \mu \mathrm{L}$ of elution buffer $(25 \mathrm{mM}$ Tris $\mathrm{pH} 8.0$, $300 \mathrm{mM} \mathrm{NaCl}, 5 \%$ glycerol, 500 mM imidazole) to each well of the filter plate and incubate for $5 \mathrm{~min}$.

11. Spin down the block to elute proteins into the 96-well PCR plate at $235 \times \mathrm{g}$ for $10 \mathrm{~min}$.

12. Seal the 96-well PCR plate with high temperature resistant tap pad and heat at $98^{\circ} \mathrm{C}$ for $3 \mathrm{~min}$.

13. Load $15 \mu \mathrm{L}$ of eluted protein samples in standard Laemmli buffer on 4-20\% SDS-PAGE gel next to the protein ladder and run the gel with standard running buffer containing SDS.

14. Stain the gel with Coomassie blue and destain with water. Analyze the results of test expression to identify the best expressing constructs for large-scale production.

\section{Preparations of the baculovirus-infected insect cells (SCBIIC) for protein production}

1. 4 days before the scheduled production time, split exponentially growing Sf9 cells to a final cell density of 2 x $10^{6}$ cells $/ \mathrm{mL}$ into $125 \mathrm{~mL} / 250 \mathrm{~mL} / 500 \mathrm{~mL}$ Erlenmeyer glass shake flasks with baffles in $50 \mathrm{~mL} / 100 \mathrm{~mL} / 200 \mathrm{~mL}$ of Insect Serum-Free medium containing 1\% (v/v) final antibiotic-antimycotic.

2. Add $0.150 \mathrm{~mL} / 0.300 \mathrm{~mL} / 0.6 \mathrm{~mL}$ of appropriate $\mathrm{P} 2$ viruses, incubate infected cells at $165 \mathrm{rpm}$ on an orbital shaker with a one-inch stroke and at a lower temperature of $25^{\circ} \mathrm{C}$ to slow down the cell division.

3. At 4 days post-infection, check cells under a microscope for SOI and proceed to production if the cell viability as verified with Trypan Blue stain is close to $70-75 \%$.

\section{Sf9 cell preparations for large-scale protein production}

1. 4 days before the scheduled production time, calculate the required volume of Sf9 cells for large-scale protein production.

2. Seed $2 \mathrm{~L}$ of exponentially growing Sf9 cells in Insect Serum-Free Medium to a cell density of $1 \times 10^{6}$ cells $/ \mathrm{mL}$ in $2.8 \mathrm{~L}$ Fernbach shake flasks.

3. Incubate flasks at $27^{\circ} \mathrm{C}$ with shaking set at $150 \mathrm{rpm}$. NOTE: To prevent bacterial contamination in the Sf9 cell culture, use gentamicin to a final concentration of $10 \mu \mathrm{g} /$ $\mathrm{mL}$ or penicillin/streptomycin to $50 \mathrm{U} / \mathrm{mL}$ and $50 \mu \mathrm{g} / \mathrm{mL}$, respectively. 


\section{Infection of the Sf9 cells with SCBIIS for the large-scale protein production}

1. Split $2 \mathrm{~L}$ or $4 \mathrm{~L}$ of exponentially growing $S f 9$ cells in Insect Serum-Free Medium to a final cell density of $4 \times 10^{6}$ cells/ $\mathrm{mL}$ in $2.5 \mathrm{~L}$ Tunair shake flasks or $5 \mathrm{~L}$ reagent bottles.

2. Add $10-12 \mathrm{~mL} / \mathrm{L}$ of the baculovirus-infected insect cell (SCBIIC) suspension culture.

3. Incubate the infected culture of Sf9 cells on a shaker with $145 \mathrm{rpm}$ at the lower temperature of $25^{\circ} \mathrm{C}$ (to slow down cell division) for 72-96 $\mathrm{h}$.

4. At $72 \mathrm{~h}$ post-infection, check cells under a microscope for SOI and assess cell viability.

5. Usually, after about $72 \mathrm{~h}$ post-infection, the viability of Sf9 cells drops to $70 \%-75 \%$ (measured using Trypan Blue stain). Harvest infected Sf9 cells in a $1 \mathrm{~L}$ polypropylene bottle by centrifugation at $900 \times g$ for $15 \mathrm{~min}$ at $4{ }^{\circ} \mathrm{C}$.

6. Resuspend the cell pellet collected from $1 \mathrm{~L}$ of the production cell culture with $20-25 \mathrm{~mL}$ of $1 \times$ PBS by gently swirling and transfer into $50 \mathrm{~mL}$ conical tubes.

7. Spin down the cell suspension at $900 \times g$ for $15 \mathrm{~min}$ and discard the PBS solution.

8. Resuspend the washed cell pellet with $20-25 \mathrm{~mL}$ of the suspension buffer $(20 \mathrm{mM}$ Tris- $\mathrm{HCl} \mathrm{pH} 8.0,500$ $\mathrm{mM} \mathrm{NaCl}, 5 \%$ glycerol, $1 \mathrm{x}$ protease inhibitor cocktail) and flash freeze in liquid nitrogen; store at $-80{ }^{\circ} \mathrm{C}$ until purification.

NOTE: Purification procedures for the PRMTs have been described in detail in the SGC published paper6 ${ }^{6}$.

\section{Representative Results}

An overview of the BEVS protocol is outlined in Figure 1. Multiple expression constructs of PRMTs, including full- length, domains, and truncated fragments, were generated at the Structural Genomics Consortium (SGC, Toronto) according to in-house strategies with an attempt to increase the success rate for identifying soluble and stable proteins with a relatively high expression level ${ }^{7,9}$. Interested readers are encouraged to review the SGC's definitions and methodology of designing a "fragment" as the segment of the gene sequence incorporated into an expression clone, "domain" as a PFAM-annotated structural domain, and "construct" as the fragment cloned in an expression vector, all of which have been described in detail in an earlier publication ${ }^{7}$. Expression constructs of PRMTs presented in this protocol are for the production of the polyhistidine-tagged proteins cloned into the $\mathrm{pFBOH}-\mathrm{MHL}$ vector, which is a derivative of the pFastBac1 vector. In Figure 4, we present SDS-PAGE analysis of the His-tagged soluble constructs of PRMT1, 2, 4-9 purified from pellets collected after 4 $\mathrm{mL}$ of production in Sf9 cells (step 3.1.4). Full-length (FL) PRMT1 and PRMT9 are not presented in this gel, since FL PRMT1 has been produced from E. coli, and FL PRMT9 produced from BEVS has been purified by Flag-tag ${ }^{6}$. The truncated constructs of PRMT1, FL PRMT4, and all the PRMT8 constructs show a relatively high yield, but protein eluates contain fractions of co-purified contaminants. These constructs require further optimization of the purification protocols. Additional approaches are thus required to improve the purity of these proteins from scale-up productions, such as a reduction in the amount of nickel beads at the stage of the incubation with a clarified lysate; an increase of the imidazole concentrations in the wash buffers; cleavage of the His-tag with TEV protease, followed by application on a Ni-affinity resin; and, additional purification steps such as size-exclusion and ion-exchange chromatography. The constructs of PRMT2 show significantly lower yield compared to other proteins and full-length PRMT2 protein accompanied 
by a strong contaminant band. Scale-up production and two steps of purifications such as IMAC and size-exclusion confirmed a low expression level for this construct along with the persistent presence of the co-purifying contaminant for the FL protein. Pure proteins have been obtained for the PRMT5 complex produced and purified with its obligate binding partner, MEP50. The truncated construct of PRMT9 has almost two or three-fold lower expression level, close to $1.5 \mathrm{mg} / \mathrm{L}$, as compared to other PRMTs. Nevertheless, the recombinant viral stocks of this construct have been used for scale-up production, diffracting crystals were obtained, and the structure was solved for this protein along with PRMT4, 6 , and 7 (Figure 5).

For the scale-up productions, the corresponding P2 viruses were used to infect the suspension culture of Sf9 insect cells. This step generates $50 / 100 / 200 \mathrm{~mL}$ of baculovirusinfected cells containing infected cells and P3 viruses in the supernatant. For the large-scale protein production, $2 \mathrm{~L}$ of Sf9 cells were cultured in each of $2.8 \mathrm{~L}$ Fernbach shake flasks at $150 \mathrm{rpm}, 27^{\circ} \mathrm{C}$ (Figure 6). On the day of production, 2 L of Sf9 cells (cell viability $>97 \%$ ) in 2.5 L Tunair shake flasks or $4 \mathrm{~L}$ in $5 \mathrm{~L}$ reagent bottles were diluted to a cell density of $4 \times 10^{6} / \mathrm{mL}$. These cells were infected directly with 10-12 mL/L of suspension culture of baculovirus-infected insect cells and incubated at a lowered temperature of 25 ${ }^{\circ} \mathrm{C}$, at $145 \mathrm{rpm}$. Infection of the production batch directly with a suspension culture of baculovirus-infected insect cells significantly reduced laborious and time-consuming steps in virus volume amplification, excluding the extra handling of the infected cells, and avoided reduction in titer and virus degradation. SF9 cell culture maintenance and scale-up production have been done in the culture vessels with a highfill volume to adopt a large-scale protein production in the one batch (Figure 6).

Full-length PRMT 4, 5 (in complex with MEP50), 6, 7, and 9 proteins produced from the Baculovirus mediated production platform have been used for kinetic characterization and inhibitor compound screening at the $\mathrm{SGC}^{6}$. Crystal structures were solved and deposited into the Protein Data Bank (PDB) for the full-length or truncated forms of the proteins PRMT 4, 6, 7, and 9 with various chemical probes and inhibitors. Expression plasmids for these PRMTs were deposited to the Addgene plasmid repository (Addgene is a distributing partner of the SGC, https://www.addgene.org/) and are available to the research community (Figure 5). 
Generating the PRMT expression constructs

ए

Transformation of expression constructs into DH10Bac E.coli competent cells

凹

Blue and white colony screening and recombinant bacmid DNA isolation

ए

Transfection of Sf9 cells with recombinant bacmid

DNA and harvest of P1 baculovirus stock from

infected cells

ए

Amplification of viral stocks from P1 to P2 by infection of Sf9 cells with P1 virus

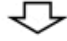

Expression screening blocks with $4 \mathrm{ml}$ of

suspension culture of Sf9 cells infected with P1 or P2 virus

ए

Test protein purification from small scale expression screening blocks

$\sqrt{3}$

SDS-PAGE analysis of the samples from the test protein purification

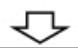

Infection of Sf9 suspension culture with the best

P2 viruses for large-scale protein production

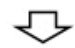

Large-scale of the baculovirus mediated PRMT protein production

Figure 1: Schematic overview of the steps of the baculovirus expression process Please click here to view a larger version of this figure. 
A.

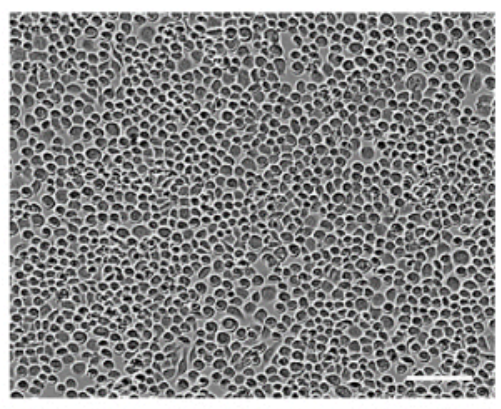

B.

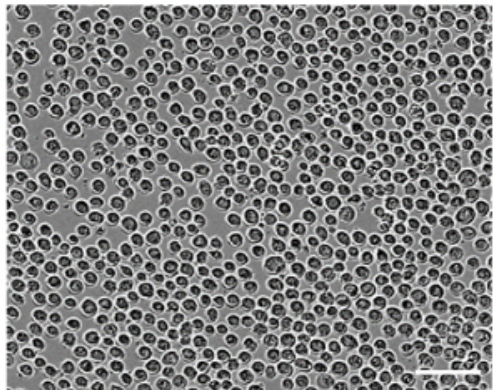

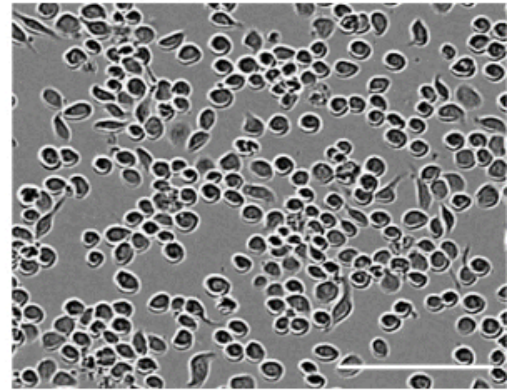

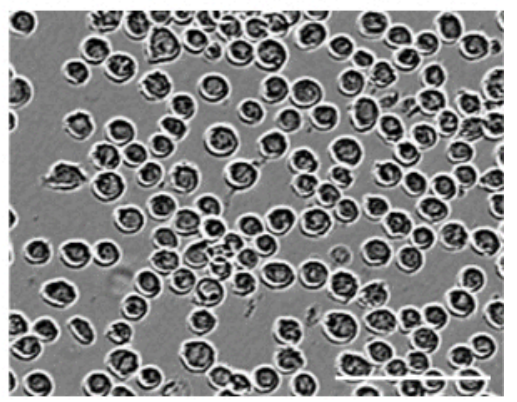

Figure 2: Baculovirus Infected and uninfected Sf9 cells. Signs of infection are structural changes in the insect cells, such as a $25-50 \%$ increase in the cell diameter, enlarged cell nuclei, uniformly rounded shape, loss of proliferation, and adherence to the culture dish surface, as well as a decrease in cell viability. White scale bar $200 \mu \mathrm{m}$. The signs of infection presented here are the same for the transfected cells using both transfection reagents, JetPrime and X-tremeGene 9. The particular example shown is for the JetPrime transfection reagent. (A) Uninfected Sf9 cells as a control. (B) Baculovirus-infected Sf9 cells. Please click here to view a larger version of this figure. 
1. Place 3 overlapping layers of parafilm on the top of the 96 deep well block (Masterblock 96 deep well $2.4 \mathrm{~mL}$ ).

2. Place a 96 well filter plate (Filter microplate, 96-well, polypropylene, with $25 \mu \mathrm{m}$ ultra high molecular weight polyethylene membrane) on the top of the 96 deep well block.

3. Push down the filter plate to secure the tips into the parafilm to seal off the filter plate from the 96 well deep block.

4. Transfer $50 \mu \mathrm{l}$ of pre-equilibrated $50 \%$ Ni-NTA resin slurry into each well of the filter plate.

5. Using a multichannel pipette, transfer the cleared lysates into a filter plate containing $50 \mu \mathrm{l}$ of pre-equilibrated $50 \%$ Ni-NTA resin slurry.

6. Seal the filter plate with a 96-well cap mat (96-well cap mat, for use with square well, $2 \mathrm{~mL}$ ).

7. Proceed to step 4 of 3.2 .2 section.

Note. Use a few rubber bands to keep the binding block together during incubation and centrifugation steps.

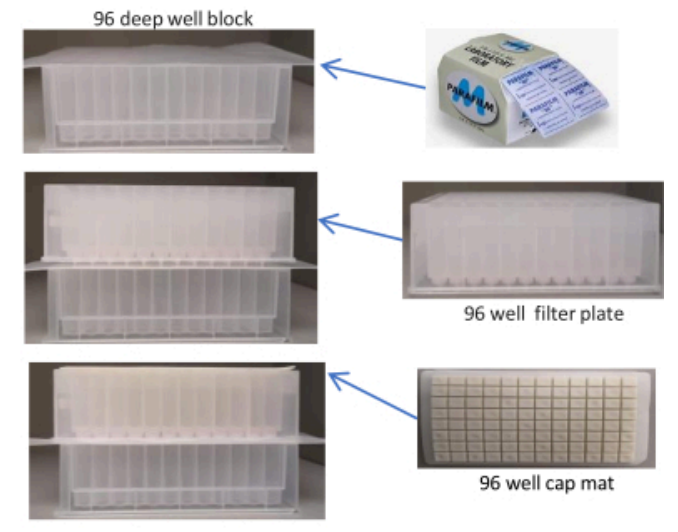

Figure 3: Binding plate assembly for quick purification of test expression proteins. Please see text for details, steps

3.2.1-2 Please click here to view a larger version of this figure. 

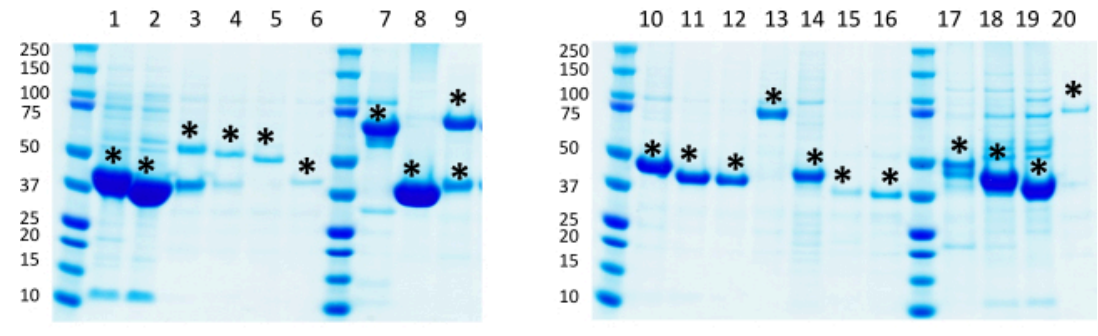

\begin{tabular}{|c|c|c|c|c|}
\hline $\begin{array}{l}\text { Lane } \\
\#\end{array}$ & Protein name & $\begin{array}{l}\text { Construct: } \\
\text { start-end } \\
\text { (amino acid } \\
\text { residues) }\end{array}$ & $\begin{array}{l}\text { Full- } \\
\text { length } \\
\text { protein }\end{array}$ & Ref Seq \\
\hline 1 & PRMT1 & $30-371$ & 371 & BC109282 \\
\hline 2 & PRMT1 & $43-371$ & 371 & BC019268 \\
\hline 3 & PRMT2 & 1- 433 & 433 & BC000727 \\
\hline 4 & PRMT2 & $13-433$ & 433 & BC000727 \\
\hline 5 & PRMT2 & $21-433$ & 433 & BC000727 \\
\hline 6 & PRMT2 & $89-433$ & 433 & BC000727 \\
\hline 7 & PRMT4 & $1-608$ & 608 & NM 199141 \\
\hline \multirow[t]{2}{*}{$\begin{array}{l}8 \\
9\end{array}$} & \begin{tabular}{|l|} 
PRMT4 \\
PRMT5
\end{tabular} & $\frac{140-480}{1-637}$ & \begin{tabular}{|l|}
6008 \\
637
\end{tabular} & \begin{tabular}{|l|} 
NM 199141 \\
BC025979
\end{tabular} \\
\hline & MEP50 & $1-342$ & 342 & BC016946 \\
\hline 10 & PRMT6 & $1-375$ & 375 & NM 018137 \\
\hline 11 & PRMT6 & $24-375$ & 375 & NM 018137 \\
\hline 12 & PRMT6 & $33-375$ & 375 & NM 018137 \\
\hline 13 & PRMT4 & 1- 692 & 692 & BC000146 \\
\hline 14 & PRMT7 & $1-356$ & 692 & BC000146 \\
\hline 15 & PRMT7 & $361-692$ & 692 & BC000146 \\
\hline 16 & PRMT7 & $369-692$ & 692 & BC000146 \\
\hline 17 & PRMT8 & $1-394$ & 394 & BC022458 \\
\hline 18 & PRMT8 & $35-394$ & 394 & BC022458 \\
\hline 19 & PRMT8 & $61-394$ & 394 & BC022458 \\
\hline 20 & PRMT9 & $127-845$ & 845 & BC064403 \\
\hline
\end{tabular}

Figure 4: Protein expression screening results. Protein expression screening results of the baculovirus mediated protein production in $4 \mathrm{~mL}$ of Sf9 suspension culture infected with corresponding P1 recombinant viruses for different PRMTs and the PRMT5-MEP50 complex. Please click here to view a larger version of this figure. 


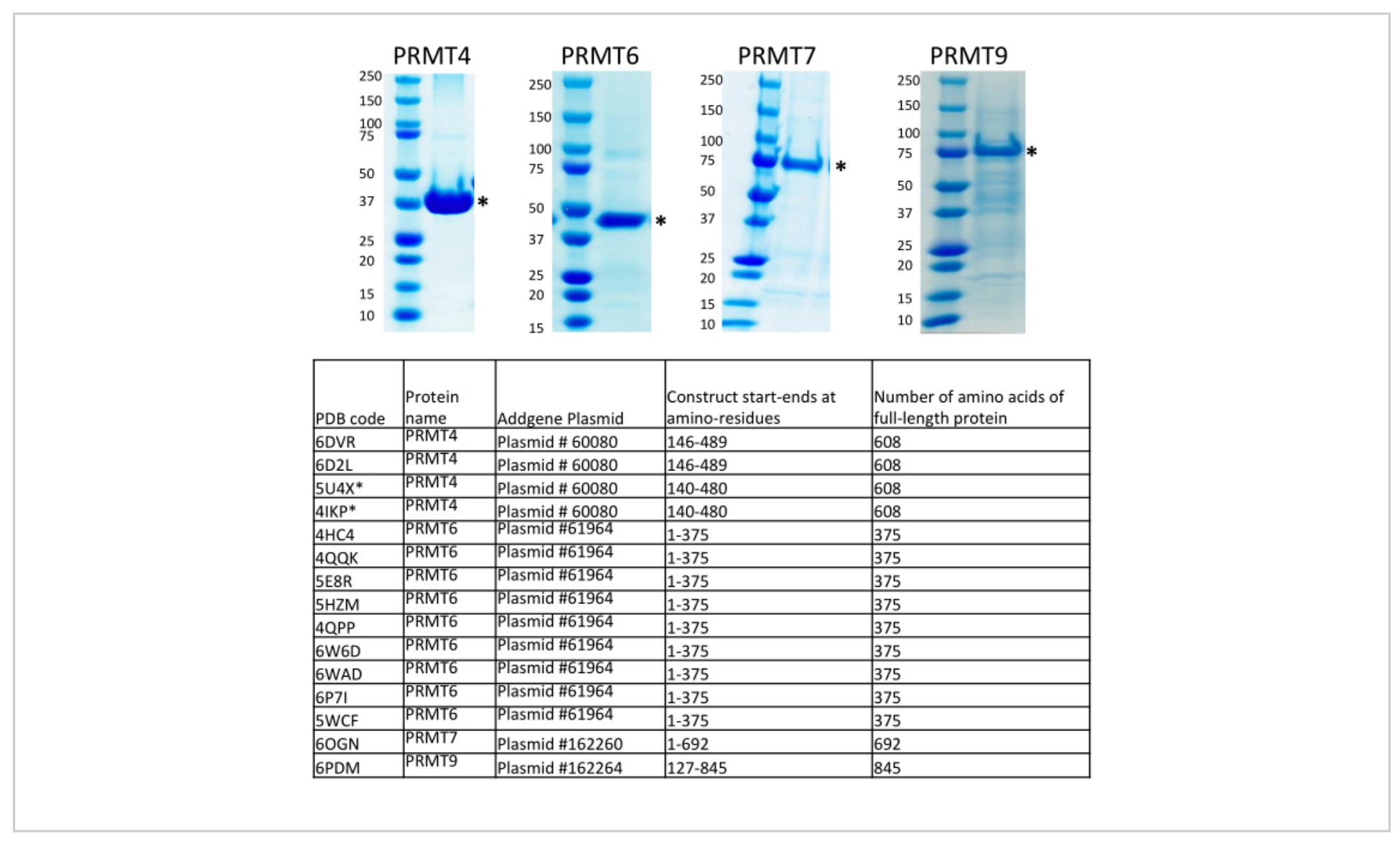

Figure 5: Summary of expression constructs for PRMT4, 6, 7, and 9 used for crystal structure studies at the Structural Genomics Consortium, Toronto (SGC). The crystal structures were solved and deposited into the Protein Data Bank (PDB) for the full length or truncated forms of proteins PRMT 4, 6, 7, and 9 with various chemical probes and inhibitors. Expression plasmids for these PRMTs were deposited to the Addgene plasmid repository and are available to the research community (Addgene is a distributing partner of the SGC, https://www.addgene.org/). Please click here to view a larger version of this figure. 
A. Growth of Sf9 insect cells and protein production in 2.8L Nalgene Fernbach Culture Flask

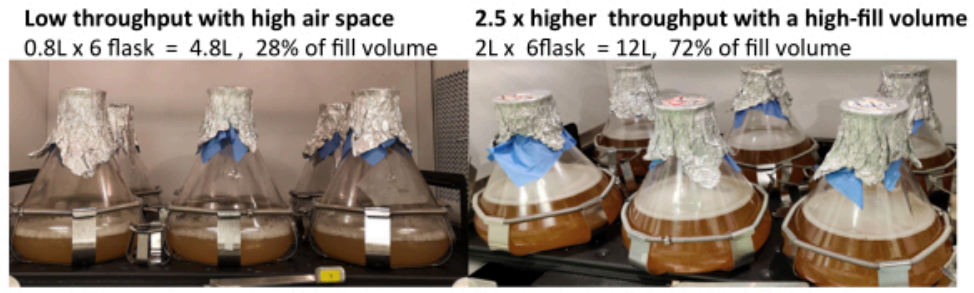

B. Growth of Sf9 insect cells and protein production in $\mathbf{2 . 5}$ Tunair shake flasks and $5 \mathrm{~L}$ reagent bottles

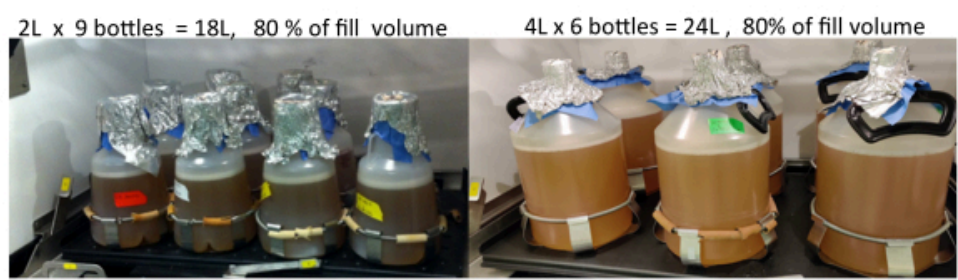

Figure 6: Sf9 insect cell maintenance and protein production in the different culture vessels: (A) $2.8 \mathrm{~L}$ Fernbach flask for cell maintenance and protein production. The use of the $72 \%$ fill-volume increases the throughput rate by 2.5 -fold in one shaking platform. (B) Tunair shake flasks (only 9 flasks out of 10 are presented in this picture) and reagent bottles with an $80 \%$ fill-volume drastically increase the shaking platform's production capacity. Please click here to view a larger version of this figure.

\section{Discussion}

One of the advantages of BEVS in insect cells centers on the capability of the post-translational modification machinery to enable more complex modifications such as phosphorylation, myristoylation, and glycosylation. Together with the highly efficient folding of mammalian proteins, these modifications facilitate high amounts of modified and folded protein suitable for physiologically relevant downstream experiments ${ }^{16}$.

Here, we described detailed protocols of the BEVS emphasizing critical elements for successful expression screening of multiple constructs of PRMT proteins and large-scale PRMT protein production in the Baculovirus expression platform: 1) The use of regular, adjustable, and programmable multichannel pipettes to transfer the biological materials between 24- and 96 - well cell culture plates and blocks at the stages of bacmid DNA and virus generation; a collection of the recombinant viruses, amplification of viral volumes of the recombinant viruses and preparation of the protein expression screening blocks. 2) High performance and cost-effective transfection reagents for the generation of recombinant viruses. 3) Suspension culture of baculovirus-infected insect cells (SCBIIC) for largescale protein production. 4) Utilization of high-fill volume 2.8 L Fernbach shake flasks to maintain Sf9 suspension culture and $2.5 \mathrm{~L}$ Tunair shake flasks and $5 \mathrm{~L}$ reagent bottles for the large-scale protein production. 
Special considerations and rationale for the transformation and transfection steps.

Although a commercial protocol recommends using $100 \mu \mathrm{L}$ of competent cells for one transformation ${ }^{14}$, the transformation efficiency of commercial DH10Bac E. coli competent cells is as high as $1 \times 10^{8} \mathrm{cfu} / \mu \mathrm{g}$ DNA, so we use only $4 \mu \mathrm{L}$. This is enough for each transformant to obtain isolated white recombinant colonies for the bacmid DNA isolation. Adherent Sf9 cells in the 24-well transfection plate were seeded at a cell density of $2 \times 10^{5} / \mathrm{mL}$ in $0.5 \mathrm{~mL}$ of Serum-Free Insect Media. This volume is enough to ensure even coverage of the working surface of the well. At the same time, it does not dilute the transfection mix too much, which enhances transfection efficiency. Transfection reagents are non-toxic to the Sf9 cells, and media exchange is not necessary. Instead of a media change, an additional $1.5 \mathrm{~mL}$ of media containing $10 \%(\mathrm{v} / \mathrm{v}) \mathrm{FBS}$ is added into the transfection plate at $4-5$ hours post-transfection time to facilitate cell growth. The transfection efficiency of both transfection reagents is high. Still, with XtremeGene 9, the signs of infection in the transfected cells (Figure 2) appear 10-12 $\mathrm{h}$ earlier than with the JetPrime reagent, so we choose between these reagents depending on the working schedule of the next steps in the protocols, which provides some flexibility in the overall process.

Protein test expression screening can be set up with P2 viruses if the amount of the initial recombinant viruses, collected from the transfection plate and labeled as $\mathrm{P} 1$, is a limiting factor to use for the protein expression screening.

Considerations when moving from small to large culture volumes.

Historically, it was believed that optimal cell growth requires a high air space in the suspension culture of Sf9 cell maintenance and scale-up productions. However, in 2014, it was reported that high air space in culture vessels is less critical than previously thought ${ }^{17}$. A culture vessel set up using appropriately adjusted shaking speed to the orbital throw of the shaking platform will provide sufficient oxygen transfer even in the high-fill volume suspension culture by creating and maintaining small air bubbles for a longer time. With this approach, commercially available insect cells can be cultured at a higher shaking speed within a normal range of the cells' doubling time without sacrificing high cell viability.

Thus, 6 years ago, we started to increase the suspension culture volume in a shaking flask during cell maintenance and introduced a different type of culture vessel for protein production while adjusting and monitoring shaking conditions (Figure 6). To establish optimal conditions in these culture vessels, we monitored the Sf9 cell culture parameters such as cell doubling time along with cell viability, size and shape, state of aggregation, and infectability of cells.

For example, for Sf9 cell maintenance, in the $2.8 \mathrm{~L}$ Fernbach shake flasks, we culture $2 \mathrm{~L}$ instead of $0.8 \mathrm{~L}$ of the Sf9 suspension cells shaking at $150 \mathrm{rpm}$ at $27^{\circ} \mathrm{C}$ and cell viability most of the time is close to $99 \%$, with evenly shaped healthy dividing cells. For scale-up production, we infect $4 \mathrm{~L}$ of cells in $5 \mathrm{~L}$ reagent bottles shaking at high speed as $145 \mathrm{rpm}$ at a lowered temperature of $25^{\circ} \mathrm{C}$. The most commonly used incubators with a built-in shaking platform can hold $6 \times 2.8 \mathrm{~L}$ shake flasks or $6 \times 5 \mathrm{~L}$ reagent bottles, or $10 \times 2.5 \mathrm{~L}$ Tunair shake flasks. Thus, the capacity of the one shaking platform, if we fill Fernbach shake flasks and reagent bottles to $1 / 3$ versus to the high-fill volume of the vessels is $4.8 \mathrm{~L}$ versus $12 \mathrm{~L}$ using $2.8 \mathrm{~L}$ Fernbach shake flasks and $10 \mathrm{~L}$ versus $24 \mathrm{~L}$ using $5 \mathrm{~L}$ reagent bottles (Figure 6). Suspension cell culture maintenance and scale-up production in the culture vessels with a high-fill volume have helped us overcome 
limitations of the production volumes and adopt a large-scale platform. Thus, this is highly useful for labs with no access to bioreactors and/or limited space in the production pipelines.

This protocol could be readily adapted for the production and purification of protein constructs with different affinity tags by utilizing appropriate resins and modifying purification buffers as has been described in the SGC published paper ${ }^{6}$ for the Flag-tagged full-length proteins of PRMT4, 7, 9, and the Histagged PRMT5-MEP50 complex and PRMT6. Although we describe a BEVS protocol for the PRMT family of proteins, the same approach can be applied to any other protein family.

\section{Disclosures}

The authors declare no conflict of interest.

\section{Acknowledgments}

The authors wish to thank Dalia Barsyte-Lovejoy for taking the time to provide valuable feedback and critical comments on the manuscript and all our SGC colleagues who worked with the PRMT protein family expressed from the Baculovirus Expression Vector System.

The SGC is a registered charity (number 1097737) that receives funds from AbbVie, Bayer AG, Boehringer Ingelheim, Genentech, Genome Canada through Ontario Genomics Institute [OGI-196], the EU and EFPIA through the Innovative Medicines Initiative 2 Joint Undertaking [EUbOPEN grant 875510], Janssen, Merck KGaA (aka EMD in Canada and US), Pfizer, Takeda and the Wellcome Trust [106169/ZZ14/Z].

\section{References}

1. Guccione, E., Richard, S. The regulation, functions and clinical relevance of arginine methylation. Nature
Reviews in Molecular Cell Biology. 20 (10), 642-657 (2019).

2. Thandapani, P., O'Connor, T. R., Bailey, T. L., Richard, S. Defining the RGG/RG motif. Molecular Cell. 50 (5), 613-623 (2013).

3. Lorton, B. M., Shechter, D. Cellular consequences of arginine methylation. Cell and Molecular Life Sciences. 76 (15), 2933-2956 (2019).

4. Bedford, M. T., Clarke, S. G. Protein arginine methylation in mammals: Who, what, and why. Molecular Cell. 33 (1), $1-13(2008)$

5. Frankel, A., Brown, J. I. Evaluation of kinetic data: What the numbers tell us about PRMTs. Biochimica Biophysica Acta Proteins Proteomics. 1867(3), 306-316 (2018).

6. Li, A. S. M., Li F., Eram, M. S., Bolotokova A., Dela Seña, C.C., Vedadi, M. Chemical probes for protein arginine methyltransferases. Methods. 175, 30-43(2020).

7. Savitsky, P. et al. High-throughput production of human proteins for crystallization: The SGC experience. Journal of Structural Biology. 172, 3-13 (2010).

8. Gileadi, O. et al. Expressing the human proteome for affinity proteomics: Optimizing expression of soluble protein domains and in vivo biotinylation. New Biotechnology. 29 (5), 515-525 (2012).

9. Graslund, S. et al. Protein production and purification. Nature Methods. 5, 135-1464 (2008).

10. Kost, T. A., Condreay, J. P., Jarvis, D. L. Baculovirus as versatile vectors for protein expression in insect and mammalian cells. Nature Biotechnology. 23, 567-575 (2005).

11. Jarvis, D. L., Baculovirus-insect cell expression systems. Methods in Enzymology. 463, 191-222 (2009). 
12. Shrestha, B. et al. Baculovirus expression vector system: an emerging host for high-throughput eukaryotic protein expression. Methods in Molecular Biology. 439, 269-289 (2008).

13. Smith, G. E., Summers, M. D., Fraser, M. J. Production of human beta interferon in insect cells infected with a baculovirus expression vector. Molecular Cell Biology. 3, 2156-2165 (1983).

14. Invitrogen. Bac-to-Bac Baculovirus expression system. Invitrogen Life Technologies, Carlsbad (2010).

15. Luckow, V. A., Lee, S. C., Barry, G. F., Olins, P. O. Efficient generation of infectious recombinant baculoviruses by site-specific transposon-mediated insertion of foreign genes into a baculovirus genome propagated in Escherichia coli. Journal of Virology. 67, 4566-4579 (1993).

16. Irons, S. L., Chambers, A. C., Lissina, O., King, L. A., Possee, R. D. Protein Production Using the Baculovirus Expression System. Current Protocol in Protein Sciences. 91, 5.5.1-5.5.22. (2018).

17. Rieffel, S. et al. Insect cell culture in reagent bottles. MethodsX. 1, 155-161 (2014). 